\title{
EXPLORING ACCEPTANCE TOWARDS ENVIRONMENTAL SUSTAINABILITY OF DISTANCE EDUCATION IN MALAYSIA
}

\author{
Siti Haslina Md HARIZAN ${ }^{1}$, Mohd. Faiz HILMI², Hanafi ATAN ${ }^{3}$ \\ ${ }^{1}$ School of Distance Education, Universiti Sains Malaysia, 11800 Penang, Malaysia, sitihaslina@usm.my \\ ${ }^{2}$ School of Distance Education, Universiti Sains Malaysia, 11800 Penang, Malaysia, faiz@usm.my \\ ${ }^{3}$ School of Distance Education, Universiti Sains Malaysia, 11800 Penang, Malaysia, ahanafi@usm.my
}

\begin{abstract}
Global warming has been among the important focus in higher educational sector worldwide. However, distance education has not been gaining sufficient attention in environmental sustainability studies of higher educational field. The overlooked dimension of sustainability in delivering courses through distance education mode has triggered a need for further understanding, in the way distance education could be acknowledged as an environmentally sustainable learning option by reducing greenhouse gas emissions. The study attempted to explore the acceptance of distance education as environmentally sustainable option among distance learners who were currently enrolled in distance education programmes in public universities located within the northern region of Malaysia. The results found that the students expressed their acceptance in the favourable manner from cognitive, affective, and conative aspects. The findings are expected to broaden the sustainability attributes of distance education and to benefit higher educational policy makers, universities' administrators, and public at large by providing evidences for environmental sustainability of distance education.
\end{abstract}

KEY WORDS Distance education, global warming, higher education, lifelong learning, online learning, environment, sustainable.

\section{INTRODUCTION}

Global warming has been an important environmental issue for decades. The scenario has called upon the need for sustainability practices in every aspect of human activities while accelerating economic growth among nations. Following the calls to combat global warming, the Malaysian government has been actively engaging in various international efforts; Montreal Protocol 1987, Kyoto Protocol 1997, COP15, UN Climate Conference in Paris 2015. In the Tenth Malaysia Plan, the government has launched the National Green Technology Policy which consists of five strategic thrust; strengthen the institutional frameworks, provide conducive environment for green technology development, intensify human capital development in green technology, intensify green technology research and innovations, and finally, promotion and public awareness [1] with the target of achieving a zero or low greenhouse gas emission. Recently, the government has also pledged to cut $\mathrm{CO} 2$ emissions intensity by $45 \%$ by 2030 [2]. Such efforts have shown that the government is very committed towards environmental sustainability. Besides being an important agenda across various economic sectors, global warming also has been a primary focus of higher learning institutions that wish to integrate sustainable concepts into their operations [3]. Maintaining sustainable environmental development has been an integral aspect to be realised by the education system since the launching of Malaysia Educational Development Plan (2001 - 2010) [4]. Due to the fact, distance education has been deemed as a learning mode which promotes sustainability in the higher education sector.

\section{BACKGROUND OF STUDY}

Research on sustainability in tertiary or higher education has been limited [5] although declarations were passed in order to achieve environmental sustainability in education which includes the inaugural in environmental education i.e. The Stockholm Declaration on the Human Environment [6] and in university's operations i.e. Kyoto Declaration [7]. The Stockholm Declaration on the Human Environment offers 24 principles in which Principle 19 stresses the need for environmental education from grade school to adulthood with the rational of nurturing responsible conduct by individuals, enterprise, and communities in protecting and improving the environment in full human dimension [6]. Kyoto Declaration states that the university community should create specific plans of action in order to pursue the goal of sustainability including the challenge, for not only promoting sustainability through environmental education, but also through the physical operations of a university [7].

To date, there is not much research which focuses on efforts to reduce greenhouse gas emissions through organisational actions [8], particularly in higher education institutions. Although there are attempts by many higher education institutions to promote sustainability, such as by green retrofitting in buildings and encouraging green practices or habits among its staffs and students such as promoting $3 \mathrm{R}$ campaign (Reduce, Reuse, and Recycling), the operational of 
distance education via online instruction is deemed as an overlooked dimension of sustainable education in mitigating the impact of global climate change [9]. As part of the important steps in providing sustainable education, the method of course delivery needs to be highlighted and acknowledged as pro-environment particularly with regard to distance learning which appears to have sustainability implications that have not been fully explored [10]. Offering courses through distance education mode may be able to result in behavioural changes with subsequent environmental impacts [11].

Research to date has yet to directly assess the link between the significance of distance education and environmental sustainability practices. As a result, students cannot truly relate the characteristics of course delivery through distance education mode to the environmental sustainability efforts [9] [12]. Therefore, the objective of the study is to explore the acceptance of distance education as an environmental sustainability learning option among distance learners who are currently enrolled in distance education programmes, run by public universities within the northern region of Malaysia. The study would suggest attributes which can be used to define acceptance of distance education as an environmentally sustainable learning option.

\section{LITERATURE REVIEW}

\subsection{Motor Vehicles and Greenhouse Gases (GHG) Emissions in Malaysia}

Air pollution has been among the major environmental issue affecting human health, agricultural crops, forest species, and ecosystem in Malaysia [13]. Motor vehicles are the major contributor to Malaysia's emission of pollutants to the atmosphere. In 2012, motor vehicles contributed 68.5 per cent of the emission of pollutants to the atmosphere as compared to stationary sources (industries including power plants) and other sources, which accounted for 26.4 per cent and 5.1 per cent respectively [14]. With the increasing numbers of motor vehicles registered in Malaysia [15], it is projected that air pollution would be greater in the future.

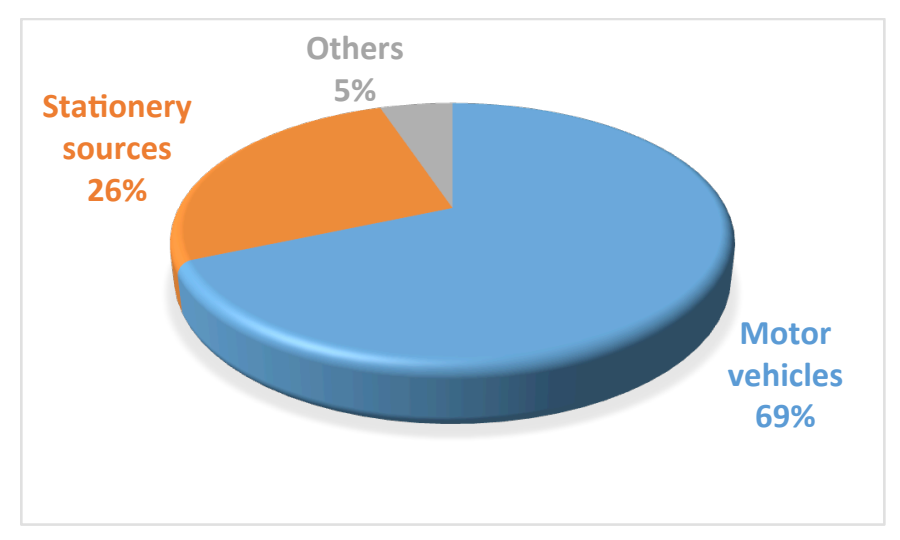

Source: Department of Statistics Malaysia [14]

Figure 1. Emission of pollutants to the atmosphere by source, Malaysia, 2012.

\section{Sources of emission in Malaysia, 2010 to 2014 (in '000 tonnes)}

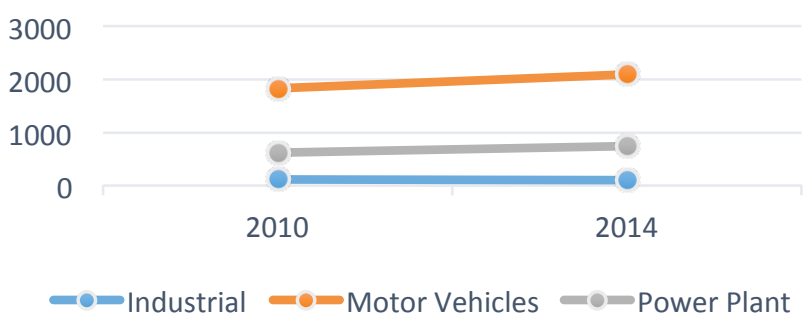

Source: Department of Statistics Malaysia [16]

Figure 2. Trends for sources of emission to the atmosphere in Malaysia, 2010 to 2014 (in '000 tonnes).

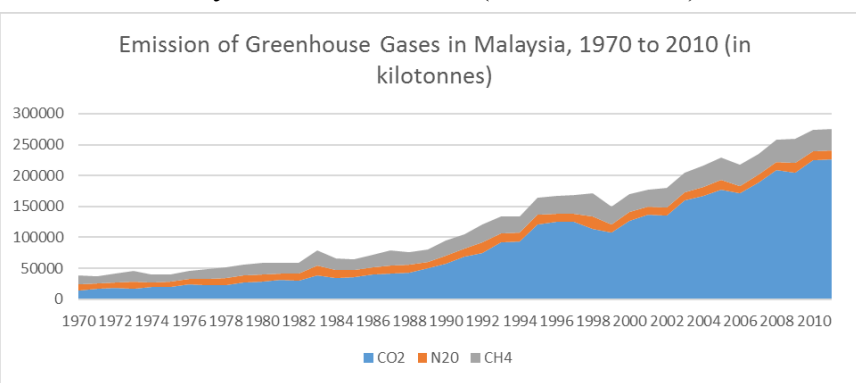

Source: World Bank [17]

Figure 3. Total emission of greenhouse gases in Malaysia from year 1970 to 2010 .

Greenhouse gas are gases which trap heat in the atmosphere and make earth warmer. Carbon dioxide forms the largest proportion of greenhouse gas emitted which contributes to climate change, followed by methane and nitrous oxide [18][19]. Greenhouse gases are hazardous to the environment as it causes air pollution which is detrimental to human health and quality of living.

\subsection{Carbon Dioxide}

Carbon dioxide $(\mathrm{CO} 2)$ is the primary greenhouse gas emitted through human activities. Carbon dioxide is naturally present in the atmosphere as part of the Earth's carbon cycle (i.e. the natural circulation of carbon among the atmosphere, oceans, soil, plants, and animals). Combustion of fossil fuels in transportation largely emits $\mathrm{CO} 2$, although other industrial processes and land-use changes also emit CO2 [20]. This also includes carbon dioxide produced during consumption of solid, liquid, gas fuels, and gas flaring [21]. The average value carbon dioxide emissions per capita for Malaysia between 1970 and 2011 was 4.01 metric tonnes with a minimum of 1.34 metric tonnes in 1970 and a maximum of 7.99 metric tonnes in 2010 [21]. For instance, high concentrations of CO2 can mainly affect respiratory function and cause excitation, which lead to depression of the central nervous system. Rapid breathing and heart rate, clumsiness, emotional upsets, fatigue, nausea, vomiting, collapse, convulsions, coma, and death could occur as the result of high and prolonged exposure [22].

\subsection{Nitrous Oxide}

Nitrous oxide (N2O) is a non-flammable, colourless gas with pleasant, sweet odour, and taste [23]. Nitrous oxide (N2O) is one of the nitrogen oxide (NOx), which is a group of air pollutants produced from combustion process [24]. N2O is 
naturally present in the atmosphere as part of earth's nitrogen cycle and has a variety of natural sources caused by human activities such as agriculture, fossil fuel combustion, wastewater management, and industrial processes. Fossil fuel combustion of motor vehicles including passenger cars and trucks remains as the significant source of $\mathrm{N} 2 \mathrm{O}$ emissions. The amount of $\mathrm{N} 2 \mathrm{O}$ emitted from transportation depends on the type of fuel and vehicle technology, maintenance, and operating practices. In Malaysia, the average emission of nitrous oxide reported from year 1970 to 2010 was $12,760.41$ kilo tonnes [17]. Moreover, the increasing trend shows that the country will be experiencing a higher amount of nitrous oxide emissions in the future. Recently, N2O was found to be the largest ozone-depletion substance emitted through human activities and is expected to remain the largest throughout the century [25]. Nitrous oxide is also known to be highly toxic to humans. Among the effects of $\mathrm{N} 2 \mathrm{O}$ to humans if exposed to high concentrations of nitrous oxide for prolonged periods are bone marrow depression and death from aplastic anaemia besides slow reaction times and performance decrements, loss of consciousness, reproductive effects, as well as acute exposure symptoms such as dizziness, difficulty in breathing, headache, nausea, fatigue, and irritability [26].

\subsection{Methane}

Methane (CH4) is a type of colourless and tasteless gas, which forms the primary component of natural gas [27]. Methane is among the major prevalent greenhouse gas emitted from human activity which is highly efficient at trapping radiation than $\mathrm{CO} 2$ [28]. Among the sources of $\mathrm{CH} 4$ are petroleum production, refinement, and storage as well as transportation, agriculture, and waste management activities. Average $\mathrm{CH} 4$ emission per year from 1970 to 2010 was reported at 24,074.02 kilo tonnes with an increasing trend throughout the year [17]. Furthermore, the potential effects of methane on human are believed to cause various adverse health effects due to methane inhalation which include agitation, slurred speech, nausea, vomiting, facial flushing, and headache. Meanwhile in severe cases, it can cause breathing and heart complications, coma and even death [27].

\subsection{Distance Education}

Distance education involves teaching methods which are delivered separately from learning activities [29]. The 'separateness' between teaching activities and learning activities is the distinctive characteristic of distance education. Most of the tools used in distance education emphasise on sharing and collaboration among students and instructors, which include course syllabus, PowerPoint presentations, and assignments [30]. Besides, instructors can share their course documents via a web tool, such as their own website or blog, or via a campus learning management system such as Blackboard or Moodle which offers additional feature of grade book integration. In addition, students can benefit from distance education tools by having a quick access to course resources and organise them while joining the course. Such distinctive characteristics of distance education programme might attract a higher number of students to enrol in such learning mode for their tertiary education.

In 2008, almost 4.6 million students enrolled in courses offered through distance learning, which formed approximately a quarter of all higher education students in the United States [30]. According to Allen [31], the growth rate exceeds the $1.2 \%$ annual growth rate of higher education enrolment overall during the same period. In Malaysia, the number of students enrolled in distance education programme have been increasing from year to year as in the following graph:

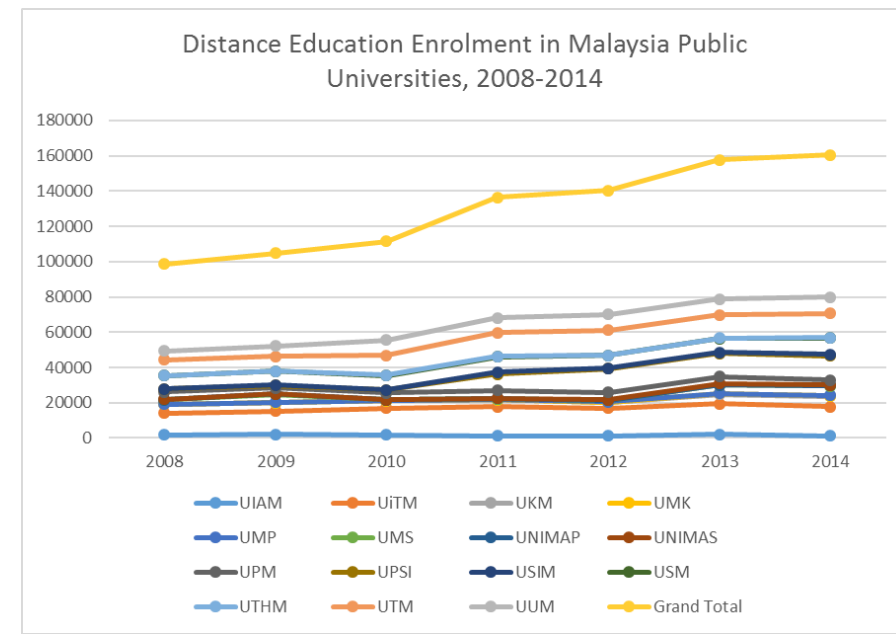

Source: Higher Education Data Centre, Ministry of Higher Education Malaysia [32]

Figure 4. Distance education enrolment in Malaysia public universities, 2008 to 2014

Looking at the steady increase of distance education enrolment in Malaysia, it is imperative to study the significant role of distance education in mitigating the need for travelling among students which may then lead towards lesser greenhouse gases emitted into the atmosphere and thus, combating global warming.

\subsection{Acceptance towards Environmental Sustainability of Distance Education}

Environmental sustainability forms one of the main pillars of sustainable development which is the "development which meets the needs of the present generation without compromising the ability of future generations to meet their own needs" [33]. Environmental sustainability as conceptualised by Goodland [34] seeks to improve human welfare by protecting the sources of raw materials used for human needs and ensuring the sinks for human wastes are not exceeded, in order to prevent harm to humans. In addition, Goodland [34] also recognises environmental sustainability as a set of constraints of four major activities which regulate the scales of human economic subsystem i.e. the use of renewable and non-renewable resources on the source side, and pollution and waste assimilation on the sink side.

Looking into the higher education aspect, distance education has much to offer in sustaining the environment. Campbell and Campbell [11] found that through distance education, the number of travelling and commuting trips to and from campus among students can be reduced. This might as well reduce the amount of greenhouse gas emission by vehicles into the atmosphere, which seems to surprise the students by the extent of environmental conservation resulted from enrolling in courses offered through distance education. In their study on 20 UK courses, Roy et.al. [10] reported that distance learning resulted in 87 per cent less energy and 85 per cent lower carbon emissions than the full-time campus-based course. The lower impacts of distance compared to full-time campus course was mainly due to a reduction in student travel and elimination of much energy consumption of students' housing. This indicates that distance education can be more sustainable than the 
conventional form of higher education [35]. The study also indicated that distance-taught courses involved 90 per cent less energy and $\mathrm{CO} 2$ emissions than campus courses, although electronic delivery did not result in a reduction in energy or $\mathrm{CO} 2$ emissions as compared to print-based distance learning. In another study of distance education in the UK, Roy, Potter, $\&$ Yarrow [10] found that distance learning delivery method consumed 87 per cent less energy and emitted 85 per cent less $\mathrm{CO} 2$ than traditional "business as usual" (BAU) classes.

Since emissions of motor vehicles are among the main sources of greenhouse gases, reducing travelling has been among the main benefits of distance education [36]. Due to such benefits as its distinct characteristics, distance education can be regarded as important to sustainable education [5] which contributes towards environmental sustainability. By reducing the number of trips required in attending face-to-face lectures, distance education can reduce emissions generated by motor vehicles into the atmosphere. Besides, it has been further anticipated that the number of students enrolled in distance education programme are increasing from year to year. Given the potential environmental savings provided by distance education via lesser needs for travelling among distance learners, the amount of GHG emissions is expected to reduce significantly.

Past researches on acceptance of distance education were mainly defined based on the technological acceptance behaviour which were operationalised within the context of ICT among users. As a result, the understanding of acceptance were bound by the attitude towards technological characteristics which solely facilitate the delivery process of elearning, distance and online courses [37][38][39] while overlooking other attitudinal aspects pertaining to sustainability. According to Oxford University Press [40], acceptance can be defined as "agreement with or belief in an idea or explanation". As belief is closely related to attitude [41], therefore, the understanding of acceptance towards environmental sustainability of distance education can be further explored based on the concept of attitude. Attitude can be defined as "a learned predisposition to behave in a consistently favourable or unfavourable way with respect to a given object" [42]. Holding a favourable attitude towards a product is almost always an essential prerequisite in order for consumers to hold a favourable purchase or consumption intentions [43]. Taylor, Hunter, and Longfellow [44] elaborated that attitude can be represented by three major components; cognitive, affective, and conative.

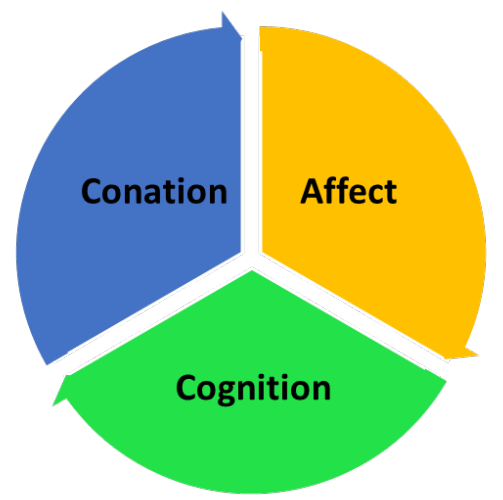

Source: Adapted from Schiffman and Wisenblit [45]

Figure 5. Tri-Component Attitude Model
The cognitive component consists of a person's cognitions, which is the knowledge and perceptions of the features of an attitude object that the person acquired from direct experience with the attitude object and information from various sources [45]. Cognitive component commonly forms into beliefs; whereby one believes that the attitude object contains various attributes which refer to the information that he/she has about a person, object, or issue [46].

On the other hand, affective component of an attitude deals with one's emotions of feelings about a particular attitude object [47]. Feelings can be understood as an affective state such as mood you are currently are in or reaction such as the feelings experienced during product consumption or processing an advertisement [43]. The affective component can also be considered as evaluations, as it captures consumer's global assessment of the attitude object which also comprises of affect-laden experiences which are manifested as "emotionally charged states" such as happiness, anger or surprise [45].

Conative component refers to the likelihood or tendency that an individual will undertake a specific action or behave in a particular way with regards to the attitude object, which may also include the actual behaviour itself [42]. The conative component is commonly treated as an expression of a consumer's intention to buy in consumer research whereby buying intention scales are used to assess the likelihood of a consumer purchasing a product or behaving in the certain way [45]. In consumer studies, pre-purchase consideration is a good indicator of actual purchase behaviour since both pre-purchase considerations and general purchase behaviour were highly correlated [48]. However, intentions may no longer play an important role in predicting actual behaviour when intervention (changes) of behaviour were involved [49]. Therefore, it is proposed in the study that the concept of acceptance be denoted by the agreements and feelings towards the idea or belief that distance education is environmentally sustainable, based on its characteristics of course delivery and future behavioural outcome of students which might be elaborated based on tricomponent attitude model.

\section{METHODOLOGY}

Four hundred distance education students currently enrolled in management and business courses via distance education mode in public universities located within the northern region of Malaysia were invited by emails to participate in an online survey. The study involved two phases of data collection. In the first phase of data collection, students were asked about their course-trip information such as mileage to/from the main campus from/to their home and main mode of transportation used to attend lectures. Data were then computed using Microsoft Excel software. Mobile emission of vehicle distance travelled method was used to obtain total emissions of greenhouse gases as a result of travelling to/from the main campus from/to their respective home in a single trip. The emissions were estimated with the aid of Carbonfund.org (2016). Data on individual student's emissions were then summed up to obtain the total emissions for $\mathrm{CO} 2, \mathrm{~N} 2 \mathrm{O}$, and CH4.

In the second phase of data collection, students who participated in the first phase of data were invited to participate in an online survey through emails. The survey was intended to obtain their opinions pertaining to acceptance of distance education as an environmental sustainability learning option. A brief information of results obtained from the first phase of 
data collection was presented at the initial part of the online survey form. The students were then asked to fill in the blank space provided in the survey questionnaires about their opinions regarding the earlier results. Students were required to state reasons underlying their opinions about the prior findings, feelings after knowing that distance education could reduce greenhouse gases significantly, and their future opinions towards it. Data gained were then analysed using NVIVO 11 software.

Word repetitions or word-counting technique was used to understand the idea behind the opinions of respondents and it has been a proper data analysis technique used in various forms of information sources; talk (interviews or focus group discussion), observations, document reviews and even drawings/photographs/video [50]. The technique is also an efficient way to start looking for themes [51]. Words repeatedly used by respondents were generated before being further validated by experts using the key-words-in-context technique [51]. A list of unique words denoting cognitive, affective, and conative components of acceptance towards environmental sustainability of distance education is presented as the outcome of the study.

\section{RESULTS AND FINDINGS}

Out of 400 invitations to fulfil the online questionnaires, only 226 completed responses were obtained, representing 56.5\% response rate and also usable rate. The majority of students were female $(62.4 \%)$, married $(53.1 \%)$, Muslims $(74.8 \%)$, Malays (72.1\%), aged between 25 to 34 years old (65.0\%), and having personal monthly income between RM 2001.00 to RM $3000.00(38.9 \%)$. Students were geographically dispersed throughout all states in Malaysia including Sabah and Sarawak.

Table 1. Environmental impact of miles driven by students in a single trip.

\begin{tabular}{|c|c|c|c|}
\hline \multicolumn{4}{|c|}{$\begin{array}{c}\text { No. of students involved: } 226 \\
\text { Student miles driven to/from campus: } 126,899\end{array}$} \\
\hline & $\mathrm{C} 02$ & N20 & $\mathrm{CH} 4$ \\
\hline $\begin{array}{l}\text { Total emissions } \\
\text { to/from campus } \\
(\mathrm{kg})\end{array}$ & $54,570.17$ & $1,796.28$ & $3,455.35$ \\
\hline $\begin{array}{l}\text { Total emissions } \\
\text { to/from campus } \\
\text { (tonnes) }\end{array}$ & 54.57 & 1.80 & 3.46 \\
\hline
\end{tabular}

Source of conversion factors: Carbonfund.org [52]

The results generated from the first phase of the survey is shown in Table 1. Overall, 226 students need to travel about $126,899.90$ miles to/from main campus from/to their home if they were to attend lectures at the main campus. This has resulted into total emissions of 54.57 tonnes for $\mathrm{CO} 2,1.80$ tonnes for $\mathrm{N} 2 \mathrm{O}$, and 3.46 tonnes for $\mathrm{CH} 4$ in a single trip. $\mathrm{CO} 2$ formed the largest greenhouse gas emitted from travelling activities of students during the course trips while $\mathrm{N} 2 \mathrm{O}$ was the least emitted for the same purpose. Data elicited from the second phase of survey were generated into a number of words before being validated by experts using key-words-in-context technique. The total word counts were 747 . Unique words representing each component of acceptance towards environmentally sustainable of distance education concept are presented as follows:

In relation to cognitive aspects, the results show that students were more likely to express words which reflected the attributes of courses delivered via distance education mode such as "saving", "helping", "environmentally-friendly", "travelling", "contributing", "minimum", "time", "protect", "reduce", "result", "support", "easy", and "flexible" in relation to its benefits to the environment, earth, life, nature, and world. Besides, students also stated the main players which helped them with the process such as "learner", "lecturer", and "worker". The state of environmental scenario was denoted by words such as "damage", "healthy", and "pollution". The methods of achieving sustainable environment through distance education were also mentioned in specific such as "knowing", "learning", "think", "activity", "awareness", "budget", "campaign", "course", "effort", "emphasis", "encourage", "involved", "knowledge", “online", "paper", "programs", "thought", "understanding", "meeting", "options", and "working". Words representing cognitive aspects ranged from $0.13 \%$ to $2.27 \%$ of the total word counts, which was the lowest among other components.

In terms of affective component, students were most likely to use words such as "good" (13.15\%) and "great" (4.54\%) to express their feelings after knowing that distance education could significantly reduce greenhouse gas emissions. The students were also "surprised", "amazed", "astonished", "impressed", "spirited", feeling "fantastic", "excellent" as well as "grateful" as they had never thought they had been chosen a mode of learning which proved to be significantly improving the quality of the environment. Some of them were also feeling "happy", "proud", and "lucky" while others felt "relieved", "responsible" and "pleasure". The percentage of repeated words denoting affective aspects ranged from $0.13 \%$ to $13.15 \%$ of the total word counts which was the highest compared to other components.

Conative aspects were represented by words such as "suggest", "continue", "enrol", "join", “continuous", "influence", "recommend", "register", and "hope" whilst among the players mentioned were "friends", "family", and "group" with the continuum ranging from "definitely/absolutely/certainly", "sure", "depends" and "willing" that would occur in the future. The percentage of repeated words pertaining to conative aspects ranged from $0.32 \%$ to $4.73 \%$ of the total word counts.

\section{DISCUSSION AND CONCLUSION}

To recap, the study attempts to explore the concept of acceptance towards distance education as an environmentallysustainable learning option. This was conducted among distance learners who were currently enrolled in distance education programmes run by public universities located within the northern region of Malaysia. Course delivery via distance education or online mode could eliminate a significant amount of greenhouse gas emissions, especially $\mathrm{CO} 2$ into the atmosphere as the students required lesser travelling trips when they can access the learning materials and attend online lectures from their home. However, distance education did not yield much reduction in greenhouse gases if the students were staying nearby the main campus as not much difference in reductions can be achieved from their travel activities. The farther the students are from the main campus, the more reduction in greenhouse gases might be achieved, provided they were fully involved in online lectures which are accessible distantly. Besides reducing the adverse impact on the environment by lesser travelling, students might be able to enjoy additional benefits when they enrolled into courses delivered through distance education mode such as minimising travelling time to/from main campus and experiencing easy and flexible way of learning. The findings provided a scientific- 
based evidence which support the environmental sustainability of distance education mode.

To further elaborate the conceptualisation of acceptance towards environmental sustainability of distance education programmes, the study attempts to explain the concept based on three main attitudinal components; cognitive, affective, and conative. From cognitive perspective, the respondents could highly associate their actions of enrolling in courses via distance education mode with its environmental impacts. Travelling was identified as the main activity in which adverse impacts of higher learning to the environment such as air pollution can be mitigated and regulated. By having lesser travelling trips among students, the numbers of active motor vehicles can be reduced and indirectly, the emission of gases that pollute the atmosphere can be reduced significantly. The 'separateness' between lecturers and students, which forms one of the main characteristics of distance education [29] offers a platform in which courses can still be delivered without students having to come to the lectures frequently. Accessible online materials such as lecture sessions, e-book, instructional multimedia courseware, and even quizzes were able to lessen travelling to/from the main campus, provided the students were well-equipped with Internet connections and other necessary tools during the lecture/learning session.

Affective component deals with the way students feel towards distance education as environmentally sustainable learning option. In this study, feelings were found to contribute the most weight in defining acceptance towards environmental sustainability of distance education. Students expressed various types of favourable feelings after they could relate the impact of their enrolment into distance education programme with the environment. Moreover, students were found to repeatedly use words such as "good", "great", and "happy" after they could associate the emissions reduction with their course trip. The study further added the kinds of feelings to the earlier narrative study by Campbell and Campbell [11] whereby the students at California State University were impressed, surprised, amazed, and even blown away after they were aware of the benefits provided by online courses to the environment.

Conative component is represented by future behavioural likelihood among the students towards distance education. From the study, students were hoping for more courses to be offered via distance education mode in the future, while expecting others such as friends and family to enrol into the programmes. The current students also expressed their willingness to complete their current distance education programmes, knowing the benefits that it provides to the environment. Ability to relate the environmental sustainability aspects with the characteristics of course delivery mode have triggered their motivations in continuing and completing their studies.

As for theoretical implications, the study contributes by highlighting components and words that were found essential to be the indicators for understanding and constructing the concept of acceptance towards environmental sustainability of distance education. Findings may assist further instrument development efforts by researchers who want to embark into sustainability research in distance education. The study may also contribute to the current body of knowledge by exploring current adoption of sustainability approaches in higher education which focus on the importance of higher educational technology used in distance education. Besides, the study may also enrich marketing research field by analysing green consumer behaviour towards accepting green service in relation to the acceptance, towards distance education as environmental sustainable in higher education sector. Practically, the study attempts to provide an avenue in which the concept of sustainability can be understood and achieved through the role of tertiary educational providers in offering courses via distance education mode. The study emphasises the importance of environmental sustainability of distance education as part of main sustainability aspects. It also strengthens additional advantages of teaching and learning using distance education mode, and provides further understanding for universities and researchers in making most contribution to sustainability. In addition, the outcome of the research also suggested that more awareness campaigns need to be done in spreading the environmental benefits of enrolling courses through distance education mode.

Nevertheless, as part of its limitations, the study has yet to account for other environmental sustainability aspects due to time and budget constraints. Future studies may look into other aspects which can be associated with the attributes of course deliverance via distance education mode such as reducing electricity usage on campus and lesser printing. Future studies may also explore the concept among distance learners from other universities located in other regions of Malaysia for variations in learners' behaviours.

As a conclusion, it has been an overlooked issue in past studies that distance education is indeed an important dimension of sustainable education in higher institutions. Behavioural changes by lesser travelling among students in large as a result of enrolling into distance education programmes may be able to mitigate significant adverse impacts on the environment, particularly in reducing greenhouse gas emissions.

\section{ACKNOWLEDGEMENTS}

This research was supported by grant no. 304/PJJAUH/6313202 from the Universiti Sains Malaysia.

\section{REFERENCES}

1. Ministry of Energy, Green Technology and Water Malaysia. (2010). The National Green Technology Policy. doi:ISBN 978-983-43893-1-4.

2. Goh, M. (2015). Malaysia pledges to cut $\mathrm{CO} 2$ emissions intensity by $45 \%$ by. Channel Newsasia, pp. 2015-2016. Retrieved from http://www.channelnewsasia.com/news/asiapacific/malays iapledgestocut/

3. Rappaport, A., \& Creighton, S. H. (2007). Degrees that matter: Climate change and the university. Cambridge, $\mathrm{M}$. A: MIT Press.

4. Ministry of Education, Malaysia. (2013). Malaysia Education Blueprint 2013 - 2025. Education. doi:10.1016/j.tate.2010.08.007.

5. Bourke, J., \& Simpson, O. (2009). Sustainability in education: Is distance learning an answer? Retrieved from http://repository.openpolytechnic.ac.nz/handle/11072/1434

6. United Nations Environment Programme (UNEP). (2003). Declaration of the United Nations Conference on the Human Environment. Retrieved May 27, 2016, from http://www.unep.org/documents.multilingual/default.asp?d ocumentid $=97 \&$ articleid $=1503$

7. International Association of Universities. (2004). Kyoto Declaration on Sustainable Development. Retrieved July 28, 2016, from http://archive.www.iauaiu.net/sd/sd_dkyoto.html 
8. American Psychological Association. (2010). Psychology and global climate change. Retrieved from http://scholar.google.com/scholar?hl=en\&um=1\&ie=UTF$8 \& 1 \mathrm{r}=\& \mathrm{q}=$ related:j4hne6K0o6Po5M:scholar.google.com/\# 1

9. May, R., Cox, V., Kroder, S., \& Franklin, G. (2011). The Overlooked Dimension of Sustainable Education. USChina Education Review, B(7), 960-974.

10. Roy, R., Potter, S., \& Yarrow, K. (2008). Designing low carbon higher education systems: Environmental impacts of campus and distance learning systems. International Journal of Sustainability in Higher Education, 9(2), 116130. Retrieved from http://www.emeraldinsight.com/journals.htm?articleid=17 22706\&show $=$ abstract

11. Campbell, J., \& Campbell, D. (2011). Distance Learning is Good for the Environment: Savings in Greenhouse Gas Emissions. Online Journal of Distance Learning Administration, 14(4), 1556-3847, Retrieved from http://www.westga.edu/ distance/ojdla/winter144/campbel 1 campell144.html

12. Din, N., Haron, S., \& Ahmad, H. (2013). The Level of Awareness on the Green ICT Concept and Self Directed Learning among Malaysian Facebook Users. ProcediaSocial and Behavioral Sciences. Retrieved from http://www.sciencedirect.com/science/article/pii/S1877042 813025020

13. Afroz, R., Hassan, M. N., \& Ibrahim, N. A. (2003). Review of air pollution and health impacts in Malaysia. Environmental Research, 92(2), 71-77. doi:10.1016/S0013-9351(02)00059-2

14. Department of Statistics Malaysia. (2013). Compendium of Environment Statistics, 1-278.

15. Ministry of Transportation, Malaysia. (2013). Transport Statistic Malaysia. Retrieved from http:/www.mot.gov.my/my/Statistik Tahunan Pengangkutan/Statistik Pengangkutan Malaysia Bagi Tahun 2013.pdf

16. Department of Statistics Malaysia. (2015). Compendium of Environment Statistics 2015. Retrieved from https://www.statistics.gov.my/index.php? $\mathrm{r}=$ column/pdfPre v\&id=YlluUUM1NGNKZ21ZRUZvYUtqV1d2Zz09

17. World Bank. (2016). World Development Indicators. Retrieved from http://data.worldbank.org/indicator/

18. Center for Climate and Energy Solutions. (2016). Main Greenhouse Gases. Retrieved July 25, 2016, from http://www.c2es.org/print/facts-figures/main-ghgs

19. United States Environmental Protection Agency (US EPA). (2014). Greenhouse Gases. Retrieved July 25, 2016, from https://www3.epa.gov/climatechange/pdfs/CIgreenhouse-gases-2014.pdf

20. United States Environmental Protection Agency (US EPA). (2016). Overview of Greenhouse Gases - Carbon Dioxide Emissions, 2-3. Retrieved from http://www3.epa.gov/climatechange/ghgemissions/gases/c o2.html

21. Theglobaleconomy.com

National_Carbon_Dioxide_Co2_Emissions_Per_Capita, 32701. - Retrieved - from http://www.theglobaleconomy.com/

22. Canadian Centre for Occupational Health and Safety. (2008). OSH answers fact sheet, 1-5. Retrieved from http://www.ccohs.ca/oshanswers/ergonomics/standing/stan ding_basic.html
23. Kaznosky, J. (2016). Nitrous Oxide: Hazards and Proper Use What is Nitrous Oxide? Retrieved July 25, 2016, from

http://www.ehs.columbia.edu/NitrousOxideHealthHazards .pdf

24. Greenfacts.org. (2004). Source document: Level 2 Details on Genetically Modified Crops.

25. Daniel, J., Ravishankara, A. R., \& Portmann, R. (2009). NOAA study shows nitrous oxide now top ozonedepleting emission. National Oceanic and Atmospheric Administration. Retrieved July 25, 2016, from http://www.noaanews.noaa.gov/stories2009/20090827_oz one.html

26. Brodsky, J. B., \& Cohen, E. N. (1986). Adverse effects of nitrous oxide. Med Toxicol, 1(5), 362-374. Retrieved from http:/www.ncbi.nlm.nih.gov/entrez/query.fcgi?cmd=Retri eve $\& \mathrm{db}=$ PubMed\&dopt $=$ Citation $\&$ list uids $=3537624$

27. Bull, S. (2010). Methane General information. UK Health Protection Agency. Retrieved from https:/www.gov.uk/government/uploads/system/uploads/a ttachment_data/file/318336/hpa_Methane_General_Infor mation_v1.pdf

28. United States Environmental Protection Agency Climate Change Division. (2014). Overview of Greenhouse Gases Methane Emissions. Government of the United States. Retrieved July 25, 2016, from http://epa.gov/climatechange/ghgemissions/gases/ch4.html

29. Mohd. Daud, M.R., Musa, M.F., Nor Azman, M.F., \& Masri'alah, M. S. (2007). Pendidikan Jarak Jauh: Isu-Isu Dalam Meningkatkan Keberkesanannya. Jurnal Teknologi Pendidikan, 1(1), 1-16. Retrieved from http://documents.tips/documents/teori-dan-prinsipdidalam-pendidikan-jarak-jauh.html

30. Dalton, E. (2012). What Is an Online Course? Quality Online Courses: A Writer's Guide. Retrieved from http://www.learninghouse.com/wpcontent/uploads/2013/08/Quality-Online-CoursesDownload.pdf\#page $=10$

31. Allen, M., Bourhis, J., Mabry, E., Burrell, N. A., \& Timmerman, C. E. (2006). Comparing distance education to face-to-face methods of education. In Classroom communication and instructional processes (pp. 229-244). Mahwah, NJ: Lawrence Erlbaum.

32. Higher Education Data Centre, Ministry of Higher Education Malaysia (2016).

33. Brundtland, G. H. (1987). Our Common Future: Report of the World Commission on Environment and Development. Medicine, Conflict and Survival (Vol. 4). doi:10.1080/07488008808408783.

34. Goodland, R. (1995). The Concept of Environmental Sustainability. Annual Review of Ecology and Systematics, 26, 1-24.

35. Herring, H., \& Roy, R. (2002). Sustainable services, electronic education and the rebound effect. Environmental Impact Assessment Review, 22(5), 525542. doi:10.1016/S0195-9255(02)00026-4.

36. Md Harizan, S.H., Hilmi, M.F., \& Atan, H. (2015). Distance Education As An Environmentally-Friendly Learning Option. Journal of Global Business and Social Entrepreneurship, 1(2), pp. 1-7. Available from http:/gbse.com.my/isi16/GBSE\%201(2),\%2017\%20(2015).pdf eISSN 24621714

37. Agudo-Peregrina, Á. F., Hernández-García, Á., \& PascualMiguel, F. J. (2014). Behavioral intention, use behavior and the acceptance of electronic learning systems: 
Differences between higher education and lifelong learning. Computers in Human Behavior, 34, 301-314. doi:10.1016/j.chb.2013.10.035.

38. Davis, F.D., \& Venkatesh, V. (1996). A critical assessment of potential measurement biases in the technology acceptance model: Three experiments. International Journal of Human-Computer Studies, 45, 19-45.

39. Selim, H. M. (2007). Critical success factors for e-learning acceptance: Confirmatory factor models. Computers \& Education, 49(2), 396-413. doi:10.1016/j.compedu.2005.09.004.

40. Oxford University Press. (2016). Acceptance. Retrieved from http://www.oxforddictionaries.com/ms/

41. Kollmuss, A. \& Agyeman, J. (2002). Mind the gap: Why do people act environmentally and what are the barriers to pro-environmental behavior? Environmental Education Research, 8(3), 239-260.

42. Schiffman, L.G., Kanuk, L.L., \& Wisenblit, J. (2010). Consumer Behavior (Tenth Ed.). Pearson Education.

43. Engel, J.F., Blackwell, R.D., \& Miniard, P. W. (1995). Consumer Behavior (8th ed.). New York: Dryden Press.

44. Taylor, S.A., Hunter, G.L., \& Longfellow, T.A. (2006). Testing an Expanded Attitude Model of Goal-Directed Behavior in a Loyalty Context. Journal of Consumer Satisfaction, Dissatisfaction and Complaining Behavior, 19, 18-39.
45. Schiffman, L.G., \& Wisenblit, J. (2015). Consumer Behavior (11th ed.). London, England: Pearson Education Limited.

46. Newhouse, N. (1991). Implications of attitude and behavior research for environmental conservation. The Journal of Environmental Education, 22(1), 26-32.

47. Allen, C.T., Machleit, K.A., Kleine, S.S., \& Notani, A. S. (2005). A Place for Emotion in Attitude Models. Journal of Business Research, 58(April), 494-499.

48. Yam-Tang, P.Y., \& Chan, Y. K. (1998). Purchasing behaviours and perceptions of environmentally-harmful products. Marketing Intelligence \& Planning, 16(6), 356362.

49. Webb, T.L., \& Sheeran, P. (2006). Does Changing Behavioral Intentions Engender Behavior Change? A Meta-Analysis of the Experimental Evidence. Psychological Bulletin, 132(2), 249-268.

50. Onwuegbuzie, A. J., Leech, N. L., \& Collins, K. M. T. (2012). Qualitative Analysis Techniques for the Review of the Literature. Qualitative Report, 17(56), 1-28.

51. Ryan, G. W., \& Bernard, H. R. (2003). Techniques to Identify Themes. Field Methods, 15(1), 85-109. doi:10.1177/1525822X02239569.

52. Carbonfund.org. (2016). How We Calculate. Retrieved May 27, 2016, from https://carbonfund.org/how-wecalculate/ 